\title{
Równi czy wspólnie? Kilka watpliwości na temat równouprawnienia i jedna próba rozwiąania
}

\section{Abstract}

At present the question of equality of women and men is non disputable. John Paul II spoke about it clearly and many times, but for most women his way of presentation of this issue was insufficient. Why? It seems that the use of the expression: „equal rights” is problematic in this context because it results in trading men against women and in proving that because we are equal, we are self-contained. This framework does not open us toward dialogue but it encloses us inside male and female worlds. Certainly it was not the intention of God, when He created us in His image and likeness as man and woman. Indeed we are His image if we are open to each other not only in mind and will but especially in the need of complementarity. Individually we can understand and recognize less than we can together so a meeting with the other sex is a chance for us to realize our potential as man and woman. For this reason, I propose to exchange the notion "equal right" for "co-rights". It does not bring a category of identity but gives the criterion of reciprocity. In the Church the "co-rights" concept is more difficult to realize in practice than the demands of feminist theology. It requires from men not only the modification of their positions but the need of awareness that they do it for themselves and not only for women. Furthermore it demands from women courage and increasing levels of expertise. However, the starting point for both genders is humility.

\section{KeYWORds}

equal right, co-right, feminism, new feminism, theology of body 
Wyszliśmy na tę wojnę wieki temu. Zwykle po stronie przegranych były kobiety. Mawiano, że dziewczynki rosną szybciej od chłopców, bo chwast rośnie szybciej od zboża. Że kobietom zbywa na sile i rozumie, a ich szerokie biodra są dowodem na to, że powinny pozostawać w domu, siedzieć cicho i zajmować się dziećmi. Kiedy młode dziewczęta chciały się uczyć, wzywano do nich doktorów i sprawdzano, czy aby nie są opętane. Głoszono, że widok kobiety myślącej jest tak samo odrażający jak widok mężczyzny z makijażem. Że kobieta nie rozumie sztuk pięknych i że absolutnie brak jej talentu. Że ma skłonność do marnotrawienia rzeczy, dlatego powinna być oddana pod opiekę mężczyzny. $Z$ natury jest słabsza, dlatego ucieka się do przebiegłości, są w niej instynktowna obłuda i skłonność do kłamstwa. Od czasu do czasu zdarzał się wprawdzie ktoś miłosierny jak Kant, kto głosił, że kobiety obdarzone są taką samą inteligencją jak mężczyźni - ale zaraz dodawał, że to tylko inteligencja piękna, męska zaś powinna być głęboka.

Takie teorie musiały znajdować swoje odbicie w praktyce życia. Jeszcze na początku xx wieku kobiety w wielu krajach Europy nie miały żadnych praw publicznych. Ruch sufrażystek wywalczył najpierw prawo do głosowania - tak stopniowo zaczął zmieniać się sposób myślenia o kobietach. Dziś o równości mężczyzn i kobiet nikt w cywilizowanym świecie nie dyskutuje. Nikomu nie przychodzi do głowy ograniczanie im praw publicznych. Owszem, zdarzy się czasem w życiu prywatnym czy - nie daj Boże! - publicznym jakiś szowinista, który uważając to za świetny żart, podkreślać będzie swoją męską wyższość. Największym jednak i niestety wciąż krępującym dziedzictwem dawnych czasów wcale nie jest już rzeczywiste zamknięcie przed kobietami konkretnych przestrzeni. Jest nim - niech panie mi wybaczą, bo w uszach wielu zabrzmi to jak herezja - frustracja. Nie jest ona całkowicie nieuzasadniona. Wieki poniżeń czy niedostrzegania kobiecego wkładu w budowanie świata wpisały się w nasz krwiobieg. Mamy prawo być wyczulone na najmniejsze nawet cienie dawnego porządku. Widzimy go czasem nawet tam, gdzie nikt nie zamierza nas dotknąć czy odsunąć. Walczymy o swoje prawa niejako na wyrost i na wszelki wypadek, upominając się o nie tam, gdzie nikt nie zamierza nam ich odebrać. Dopóki skupiać się będziemy na takiej właśnie walce, nie zrobimy już ani kroku do przodu. Dziś bowiem to nie brak obiektywnej równości, ale właśnie owa frustracja powoduje, że mężczyźni i kobiety, choć wojna oficjalnie została zakończona, pozostają wciąż po dwóch stronach barykady. 


\section{Co NAM ZROBIŁ SOBÓR}

W Kościele jeszcze w latach 6o. xx wieku sytuacja kobiet nie wyglądała dobrze. Karl Rahner pisał: „Chrześcijaństwo w swej zasadniczej treści nie zawiera nic specyficznie kobiecego. Zostało ustanowione przez mężczyznę, jego przekaz głosi królestwo Boga, jego oficjalnymi przedstawicielami są mężczyźni. Mężczyźni są też tymi, którzy w jego historii podejmują akcje decydujące, wypowiadają słowa wielkiej wagi. Czytając Pismo Swięte, trudno nawet udowodnić, że chrześcijaństwo przyznaje kobiecie należne jej miejsce i rangę".

Być może pierwszym wyraźnym głosem w obronie kobiet była encyklika Pacem in terris (1963), w której papież Jan xxıI promocję kobiet nazwał „znakiem czasu”. Chwilę później, w 1965 roku Sobór Watykański II wydał Orędzie do kobiet. Ojcowie soborowi zapisali w nim: „Nadchodzi godzina, nadeszła już godzina, w której powołanie niewiasty realizuje się w pełni. Godzina, w której niewiasta swoim wpływem promieniuje na społeczeństwo i uzyskuje władzę nigdy dotąd nie posiadaną".

To musiało dodać kobietom odwagi. W latach 6o. powstały pierwsze książki o roli kobiety w Kościele, krótko potem zaczęto wypracowywać koncepcje teologii feministycznych. Ich założeniem było przekonanie, że skoro teologia jest osobistym świadczeniem o wierze, to uprawiana przez kobiety winna być uprawiana $z$ ich perspektywy i czerpać $z$ ich doświadczeń.

\section{Co nam zrobie Jan Pawee iI}

Nauczanie Jana Pawła II było w Kościele nowością. Dziś jednak trudno się oprzeć wrażeniu, że choć papież powiedział o kobietach bardzo dużo, to powiedział wciąż za mało. „Za mało” nie dotyczy tu ilości, ale raczej jakości myślenia o kobietach. Docenione wprawdzie i ustawione na piedestale kobiety ukazywane są raczej jako uzupełnienie, dopełnienie albo zwieńczenie człowieczeństwa, a nie człowieczeństwo samo w sobie. Daleka tu jestem od rzucania oskarżeń. Rozumiem, że Jan Paweł II pozostawał dzieckiem swoich czasów i jako taki wyszedł daleko przed szereg. To my dopiero dziś potrafimy nazwać to, co w tamtym

I K. Rahner, O możliwości wiary dzisiaj, Kraków I983, s. 230. 
nauczaniu pozostawiało $\mathrm{w}$ nas niedosyt czy wręcz niesmak. A może po prostu nie wyciągnęliśmy $\mathrm{z}$ niego odpowiednich wniosków?

Paradoksalnie największy opór kobiet budzi w papieskim nauczaniu to, co w założeniu miało być hołdem im złożonym. Sformułowanie "geniusz kobiety" wcale nie jest w środowiskach kobiecych przyjmowane z zachwytem. Geniusz ten polegać ma miłości i wprowadzaniu jej porządku w świat obok męskiego, dominującego porządku władzy, na radykalnej afirmacji życia ${ }^{2}$, na sile w wyznawaniu wiary ${ }^{3}$. Zadaniami kobiety są więc według Jana Pawła II głównie aktywna obecność w rodzinach i macierzyństwo. W liście papież snuje słynną listę podziękowań dla kobiety: matki, małżonki, kobiety konsekrowanej, kształtującej kulturę - „za to, że jesteś kobietą”.

Nie mogą tu się nie cisnąć na usta pytania: skoro kobieta rzeczywiście uważana jest przez papieża za równą mężczyźnie i komplementarną, a nie tylko uzupełniająca go w człowieczeństwie, dlaczego nigdy nie powstał podobny hymn pochwalny na temat mężczyzny. Dlaczego o jego geniuszu nikt nie mówi? W uszach kobiet brzmi to trochę jak przekonywanie, że „kobieta też człowiek” - z akcentem na „też”. Jeśli komuś przychodzi do głowy takie przekonywanie, to znaczy, że problem wciąż jednak jest: nikt nas nie przekonuje, że musimy każdego dnia oddychać. Można zachwycać się kobietami, mówić im tysiące komplementów i napisać tomy na temat ich niepodważalnej roli: ale dopóki trzeba o tym mówić, to znaczy, że owej równości nie ma. $\mathrm{O}$ „geniuszu kobiety” mówić można tak długo, dopóki zauważa się najpierw kobiecość, potem człowieczeństwo. I jeśli kobiety są dziś nadal sfrustrowane, jeśli nadal chcą walczyć, to właśnie o to: żeby postrzegane były jako ludzie, którzy są kobietami, a nie jako kobiety, które „też” są ludźmi.

\section{Co ROBImy SOBIE SAME}

Nie jest to jednak uwaga tylko do mężczyzn. Jakiś czas temu brałam udział w konferencji naukowej, na której pośród kilkunastu referatów

\footnotetext{
3 Por. Jan Paweł II, list Mulieris dignitatem, 15.

4 Por.Jan Paweł II, List do kobiet, 2.
} Przekazu.

2 Por. Jan Paweł II, Orędzie na xxx Światowy Dzień Środków Społecznego 
tylko jeden głosiła kobieta. Rzecz dotyczyła zagadnień teologicznych, w żaden sposób niezwiązanych $\mathrm{z}$ kobiecością. Powinnam $\mathrm{z}$ owej pani być dumna i czuć $z$ nią solidarność. Niestety - nie dało się. Pani była nieprzygotowana, niekompetentna, a braki merytoryczne próbowała nadrabiać wdzięczeniem się do słuchaczy. Nikt potem nie ośmielił się dać jej żadnej informacji zwrotnej, obawiając się - pewnie słusznie posądzenia o dyskryminację kobiet.

Nikt nie robi większej szkody kobiecej sprawie niż niekompetentne kobiety, które wchodząc w najróżniejsze środowiska, zamiast być świetnymi naukowcami, wykładowcami, specjalistkami, dziennikarkami, potrafią mówić głównie o tym, że są kobietami i że walczą o kobiece prawo do głosu. Od ponad dwudziestu lat obracam się w przeróżnych środowiskach okołokościelnych, wyraźnie zmaskulinizowanych, wręcz sklerykalizowanych. Być może mam wiele szczęścia i moje doświadczenie jest jednostkowe. Doświadczam jednak, że to wcale nie bycie kobietą otwiera mi czy zamyka kolejne drzwi. Pierwszym murem, z jakim spotykam się w Kościele, jest bycie osobą świecką. Jeśli ten mur uda się sforsować, to fakt bycia mężczyzną czy kobietą nie ma już znaczenia: zaczynają się liczyć kompetencje. Oczywiście pod warunkiem, że te kompetencje rzeczywiście są i nie próbuje się ich zastępować argumentami o parytetach, prawach kobiet czy - o zgrozo! - trzepotaniem rzęsami. Można by tu znów wchodzić w rozważania na temat tego, jakie miejsce dla kobiet przewidywał w Kościele Jan Paweł II, ale świadomie tego nie robię. Uważam, że nie ma to większego znaczenia. Jeśli bowiem rzeczywiście będziemy kompetentne, jeśli znajdziemy w sobie odwagę do zabierania głosu, jeśli będziemy to robić rzeczowo, bez agresji i pretensji, to zostaniemy wysłuchane. Co więcej: do żadnych drzwi nie będziemy musiały się dobijać. Ci po drugiej stronie sami nas znajdą i przyjdą po pomoc. I to niekoniecznie wyłącznie na tych polach, jakie przewidział i zapisał dla nas papież.

\section{Co NAM ZRobiŁA „RÓWNość”}

Mówiąc o relacji „kobieta-mężczyzna”, przyzwyczailiśmy się używać terminu „równouprawnienie”. Dzięki równouprawnieniu kobiety sięgają tam, gdzie dotychczas byli tylko mężczyźni. Zostały uznane za jednakowo zdolne do pełnienia funkcji i zajmowania stanowisk. Zyskały prawo udowadniania, że są „,ównie dobre”, jak mężczyźni, że mogą egzystować 
samodzielnie i niezależnie od mężczyzn. I świetnie dają sobie radę. Tyle że ostatecznie nikomu nie wychodzi to na dobre i nie sprawia wcale, że jesteśmy szczęśliwsi. Frustracja, od której zaczęłam, wciąż się w nas tli.

Teologia feministyczna, wyrastająca obok „patriarchalnej”, szuka nowych kobiecych wzorców w Starym i Nowym Testamencie, próbuje Boga nazywać „Matką”. Zasadnicze pytanie brzmi jednak: czy to rzeczywiście wyzwala nas ze schematów, czy tylko zamyka w innych, równie ułomnych, bo jednostronnych? Czy kobiety doskonale radzące sobie bez dorobku i myśli mężczyzn nie tworzą jednocześnie świata przypominającego Seksmisje Juliusza Machulskiego, w której mężczyzna jest już tylko archeologiczną ciekawostką, niebędącą w stanie w niczym uzupełnić przestrzeni kobiecej? Czy zamiast leczyć, nie pogłębiamy ran Kościoła, dzieląc go jeszcze bardziej i według nowych kryteriów? W spotkaniu teologii feministycznej z tzw. „patriarchalną” zyskujemy wprawdzie dwa różne spojrzenia i nie jest to pozbawione pewnej wartości. Nadal jednak człowiek musi wybrać, po której stronie staje - i jego własne doświadczenie pozostaje tak samo ubogie i tak samo jednostronne.

Jesteśmy równi. Co to w gruncie rzeczy znaczy? Jedni i drudzy jesteśmy w stanie robić wszystko - dlatego zaczęliśmy robić wszystko sami. Staliśmy się samowystarczalni i zdolni zastępować się w swoich rolach. Nie wszędzie jest to niepokojące. Tam, gdzie jest miłość, nie dzieje się nic złego: kobiety zarabiają na dom i wbijają gwoździe, mężczyźni opiekują się dziećmi i świetnie gotują, a ich wzajemne zastępowanie się nie jest źródłem nieszczęścia. Tam jednak, gdzie miłości między dwiema osobami nie ma - w relacjach społecznych czy w Kościele - samowystarczalność oznacza zubożenie. Sprawia, że zamiast szukać drugiego, rywalizujemy ze sobą i ostatecznie od siebie się oddalamy. W imię samowystarczalności i „równości” dobrowolnie (i lekkomyślnie) rezygnujemy z tego, czym drugi - inny może nas ubogacić. Czy mamy prawo do takiego zubożenia siebie? Czy to na pewno jest wypełnianie woli Boga, który zapewne wiedział, co robi, stwarzając mężczyznę i kobietę tak różnymi?

\section{KROK Wstecz}

Podsumowując wcześniejsze: widać wyraźnie, że mamy problem, z którym na drodze „równości” nie możemy już dalej pójść. Żaden następny 
krok nie sprawia, że jako „równi”, ,jednakowo zdolni” i „samowystarczalni" dogadujemy się lepiej. Skoro zatem nie można iść do przodu bez toczenia wojny, zróbmy krok wstecz. Wróćmy na chwilę do nauczania papieża Jana Pawła II, bo właśnie w nim kryje się dla nas pewna inspiracja.Jeśli nie pozostawać na poziomie prostego odbioru, ale spróbować wyciągać praktycznie wnioski, może się okazać, że znajdziemy ciekawą podpowiedź.

Szczególne wrażenie $\mathrm{w}$ nauczaniu papieża robiło to wszystko, co dotyczyło teologii ciała, czyli sfery, o której w Kościele nikt wcześniej w ten sposób nie mówił. To nie tylko dusza, ale również ciało kobiety i mężczyzny są dla papieża dowodem na bycie stworzonym na obraz i podobieństwo Boga. To płeć wyznacza miejsce człowieka przez Bogiem i ludzkością, a cielesny człowiek, na podobieństwo Boga w Trójcy, nie może pozostawać sam - jego zadaniem jest wchodzenie $\mathrm{w}$ nieustanną relację $\mathrm{z}$ drugą płciąa . Co więcej, z papieskiej myśli wyni$\mathrm{ka}, \dot{z ̇ e}$ ani kobieta, ani mężczyzna nie są obrazem Boga w swoim intelekcie czy woli, ale są nim poprzez swoją komplementarność, poprzez bycie $\mathrm{w}$ nieustannym, wzajemnym odniesieniu? Pierwotną jedność człowieka jako kobiety i mężczyzny zniszczył grzech pierworodny. Zachwiał on również pierwotnym znaczeniem ciała jako tworzywa komunii: zniknęła prostota i czystość przeżycia, a pojawił się wstyd ${ }^{8}$. Papież twierdzi, że owemu przeciwstawieniu płci i w efekcie potraktowaniu kobiety jako człowieka niższej kategorii przeciwstawił się Chrystus, który powrócił do początków stworzenia. Teraz doskonalenie relacji między kobietą i mężczyzną ma być przezwyciężaniem logiki grzechu'

Teologia feministyczna, poszukując ,źródeł wyzwolenia kobiet”, badając kobiece tradycje w Biblii i w historii Kościoła, uczyniła ważną rzecz: przywróciła kobietę na pozycję partnera, udowodniła jej „równość”. Ale już z opisu stworzenia wynika, że Bogu nie o równouprawnienie

5 Por.J. Bajda, Chrystus odwotuje się do „serca”. Wokót problemu interioryzacji, w: Jan Paweł II, Mężczyznq i niewiasta stworzyt ich. Chrystus odwotuje się do "serca”. O Jana Pawta II teologii ciata, Lublin I987, s. 158-I59.

6 Por. Kongregacja Nauki Wiary, List do biskupów Kościota katolickiego o wspótdziataniu mężczyzny i kobiety w Kościele i świecie, 6.

7 Por. G. Weigel, Świadek nadziei, tłum. M. Tarnowska i in., Kraków 2000, s. 426.

8 Por. Jan Paweł II, Mężczyznq i niewiasta stworzyt ich. Chrystus odwotuje sie do „serca”..., dz. cyt., s. 34 .

9 Por. Kongregacja Nauki Wiary, List do biskupów Kościoła katolickiego o współdziałaniu mężczyzny i kobiety w Kościele i świecie, 8 . 
chodziło, ale o coś większego. Stworzeni zostaliśmy jako różni od siebie i na co dzień boleśnie tego doświadczamy. Bóg jednak nie zamierzał bronić kobiety przed mężczyzną ani mężczyzny przed kobietą, nie zamierzał nas chronić przed tymi różnicami. Zaplanował je dla nas jako nasze szczęście. Księga Rodzaju odnotowuje Bożą myśl: „nie jest dobrze, żeby człowiek był sam”, która zaowocowała stworzeniem „odpowiedniej pomocy” - kobiety. Bóg wiedział, że jesteśmy ograniczeni naszą płcią. Wiedział, że pojedynczo możemy mniej. Że wiemy, widzimy, czujemy, rozumiemy tylko na swój własny - kobiecy lub męski sposób. Dlatego stworzył nas „mężczyzną i niewiastą”: dał nam w ten sposób szansę na odnalezienie całości, na czytanie dużo szerszej (może pełnej?) perspektywy.

\section{Co MOŻEMY ZROBIĆ?}

Żebyśmy mogli się wzajemnie ubogacać bez poczucia fałszywej wyższości i niższości oraz bez równie fałszywej izolacji; żebyśmy mogli rzeczywiście szukać „całości”, trzeba ponad terminem „równości” szukać innego, który pozwoli nam nie tylko iść obok siebie, ale iść, trzymając się za ręce i wspólnie malując obraz świata i obraz Boga.

Być może jedno pojęcie nie zmieni rzeczywistości, ale lepiej zacząć od drobnego kroku, niż nadal stać w miejscu. Dlatego proponuję, żeby w miejsce wyczerpanego już w swoich żądaniach „równouprawnienia” wprowadzić nowy, głębszy termin, wypływający pośrednio $\mathrm{z}$ „teologii ciała” Jana Pawła Iı: „współuprawnienie”. Nie wprowadza on kategorii jednakowości, choć obu płciom pozostawia tę samą godność. Więcej: dodaje kryterium wzajemnej niezbędności. Nie pozwala więcej na dzielenie świata na przestrzenie „kobiece” $i$ „męskie”, ale we wszystkim każe jednym i drugim, w ścisłej łączności ze sobą, podejmować odpowiedzialność jednakowo wielką, ale różną co do sposobów działania.

Równouprawnienie nie brało pod uwage naturalnych różnic i predyspozycji. W gruncie rzeczy ignorowało zatem to, co determinuje nasze postrzeganie świata, co wyznacza nasze relacje, co zbliża nas do Boga: ignorowało naszą męskość i kobiecość. Nie miało znaczenia, czy nasze człowieczeństwo wyrażało się przez kobiecość, czy przez męskość: mieliśmy we wszystkim być równi. Nie proponuję, żebyśmy we wszystkim byli równi. Proponuję rzecz trudniejszą, do której być możne już dorastamy: żebyśmy we wszystkim byli razem, za wszystko wspólnie odpowiedzialni, uzupełniający się nawzajem. 


\section{Wspólnie w Kościele}

W życiu Kościoła - bo to interesuje mnie najbardziej - „współuprawnienie" będzie dużo trudniejsze niż feminizm. Teolożki feministyczne mogły głosić swoje teorie na niektórych katedrach i na sympozjach, które same sobie organizowały, i często nikogo poza ich wąskim gronem to nie interesowało. „Współuprawnienie” zakłada, żeby kobiety będą obecne nie we własnym świecie, ale tuż obok: na katedrach, w duszpasterstwie, obok księdza, obok biskupa. Oznacza zgodę nie tylko na ich obecność, ale również na wymianę myśli, spory, kompromisy, wspólne planowanie i wspólne rezygnowanie. Oznacza jednocześnie, że jedna i druga strona będzie musiała uczyć się pokory. Nie zawsze ksiądz będzie miał rację. Nie zawsze kobieta będzie miała rację. Racja będzie tam, gdzie wspólnie ją znajdą.

Feminizm, przynajmniej teoretycznie, mógł istnieć w Kościele i nigdy nie spotkać się $\mathrm{z}$ „dawną” myślą patriarchalną. Sama znam księży, którzy nigdy nie zniżyli się do partnerskiej rozmowy z kobietą, a dostrzegali jedynie te, które zdobyły tytuł doktora teologii. Jeszcze innym nawet to nie wystarczało, by się z nimi choćby przywitać. „Współuprawnienie” niesie ze sobą ryzyko relacji, z całym jej pięknem i bólem.

Odpowiadanie myślą feministyczną na myśl patriarchalną powoduje, że wciąż tkwimy w błędzie pojedynczości. Potrzeba bycia wspólnie i razem, żeby zacząć widzieć więcej: żeby nawzajem pokazać sobie nasze światy. To, o czym piszę, to nie są rzeczy nowe. W gruncie rzeczy Kościół zna je od lat, choć nie zawsze głośno się do nich przyznawano. Ale Bóg pozwalał spotykać się męsko-damskim duetom: od św. Pawła i św. Lidii, Hildegardy z Bingen i Bernarda z Clairvaux, poprzez Klarę i Franciszka, Teresę z Ávilai i Jana od Krzyża, po Hansa Ursa von Baltasara i Adrienne von Speyr. Kobiety nie były tam maskotkami, ale w wyraźny sposób budowały wspólną teologię. Nie jest przecież możliwe, by boskie „nie jest dobrze, żeby mężczyzna był sam” dotyczyło całej ziemskiej rzeczywistości, oprócz rzeczywistości Kościoła. Takie myślenie czyniłoby Kościól ułomnym, zawężało boleśnie jego myślenie i wrażliwość, ograniczało przestrzenie jego działania. 


\section{WS PÓLNIE W CELIBACIE}

Również celibat nie może oznaczać deklaracji: „nie potrzebuję kobiety”. Byłoby to deprecjonowaniem jej godności i uznaniem, że nie jest ona w stanie niczego nowego wnieść do osobowości mężczyzny. Niestety wciąż jeszcze kobieta w życiu kapłana traktowana jest albo jako zagrożenie, albo jako duszyczka do zaopiekowania. Wciąż niewielu księży ma odwage dostrzec w kobiecie partnera: jakby stawiali siebie ponad prawdą stworzenia, że Bóg stworzył ich razem, by byli sobie pomocą, a celibat zamykat ich na wszelkie relacje.

Celibat jest wartością - ale nie wartością ostateczną. Nie ma służyć księdzu, ale Kościołowi. Jest zobowiązaniem bezżenności, a co za tym idzie - do czystości, ale nie jest przyrzeczeniem zamknięcia się na wszelkie relacje. W żadnej mierze nie może oznaczać takiego zamknięcia, które ograniczy księdza w jego ludzkim rozwoju.

Znam seminaria duchowne, w których klerycy przez sześć lat formacji nie spotykają żadnych kobiet poza emerytowanymi zakonnicami. W których relacje $\mathrm{z}$ kobietami zrywa się natychmiast, gdy tylko pojawiają się w nich emocje. Zamiast nad relacjami pracować, łatwiej jest je na wszelki wypadek odrzucić i pozostać w swoim „bezpiecznym” świecie. Ale jak potem dostrzec w kobietach partnerki do poznawania i uświęcania świata? Gdzie się nauczyć, że kobieta to ani głupia baba, ani obiekt seksualny? Gdzie zauważyć, że warto czasem posłuchać kobiety: nie dla jej, ale dla swojego własnego dobra? I co ważniejsze: dla dobra Kościoła, dla dobra słuchaczy, penitentów, dzieci, rodzin? Gdzie się nauczyć, że kobieta nie jest potrzebna mężczyźnie tylko do łóżka, ale do tego, żeby był mądrzejszy i lepiej rozumiał świat?

Trzeba to mocno podkreślać - kapłan, tak samo jak każdy mężczyzna, potrzebuje obecności kobiety: siostry, matki, siostry zakonnej, kobiety żyjącej w małżeństwie. Potrzebuje jej nie tylko dla swojego życia osobistego, ale potrzebuje jej we wspólnocie, dla głoszenia, dla duszpasterstwa, dla katechezy, dla tych, którym sam ma służyć. Ani mężczyzna, ani kobieta nie mogą tu stawać na pozycji silniejszego: uzupełniają się bowiem w służbie Kościołowi. 


\section{WSPÓLNIE W PRAKTYCE}

Nie jestem teoretykiem. Termin „współuprawnienia” pojawił się nie jako droga wyjścia, ale jako owoc wielu lat doświadczeń w katechezie i pracy przy parafii. Kosztował wiele nerwów i ciężkiej pracy, ale wiem, że było warto. I jestem wdzięczna ludziom, z którymi wspólnie, jeszcze przed nazwaniem rzeczy po imieniu, go testowaliśmy.

Sprawdziłam, więc wiem, że w pracy naukowej, w duszpasterstwach diecezjalnych i parafialnych, w seminariach duchownych warto zadbać o obecność mądrych kobiet. Niech nie tylko studiują, ale i wykładają. Niech prowadzą wydziały w kuriach, niech będą dyrektorkami poszczególnych instytucji, niech znajdują miejsce tam, gdzie są kompetentne: żeby ksiądz mógł być tam, gdzie go nikt nie zastąpi: przy ołtarzu i w konfesjonale.

Niech prowadzą wspólnie z księżmi grupy parafialne, zwłaszcza te dla dzieci i młodzieży, w których na równi potrzeba duchowego ojca i matki. Niech będą obecne w rzeczywistej formacji przyszłych kapłanów i niech uczą relacji, której nie zdeterminuje seksualność.

Chciałabym być dobrze zrozumiana: nie domagam się kościelnego parytetu dla kobiet. Nie chodzi o to, by wszędzie na siłę stawiać w Kościele kobiety, niezależnie od poziomu ich wiedzy, umiejętności i moralności. Warto jednak zadbać o to, by żony, matki i siostry zakonne, jeśli tylko będą do tego przygotowane, mogły w poczuciu wspólnej troski podejmować współodpowiedzialność. By nikt się nimi nie posługiwał ani nie wyręczał, ale traktowal ich obecność jako niezbędną i oczywistą dla prawidłowego rozwoju wspólnoty. Chodzi o to, żeby ich szukał ze świadomością, że bez nich, bez ich obecności i odpowiedzialności na nich złożonej, każde działanie będzie ułomne. Każde.

\section{IO. WSPÓLNIE POD WARUNKIEM}

„Współuprawnienie” jest trudne dla obu stron. Żeby mogło przynieść owoce, trzeba spełnić kilka warunków. Pierwszym jest intencja. Jeśli spotykamy się, rozmawiamy i pracujemy razem $z$ innego powodu, niż głoszenie Jezusa $Z$ martwychwstałego, prawie na pewno prędzej czy później od Niego odejdziemy. Dobro Kościoła powinno być jedynym celem podejmowanych razem działań. Drugim warunkiem jest odwaga myśli. Zarówno kobiety, jak i mężczyźni powinni uczyć się jasno 
wyrażać swoje poglądy, emocje i hipotezy, bez wstydu i poddaństwa po to, by spotkanie myśli było owocne $\mathrm{i}$ by nie stawiać granic Bożej Prawdzie, która chce się przez nas wyrażać. Warunkiem trzecim, wcale nie najmniej istotnym, jest pragnienie czystości. To trudność podwójna, bo nieustannie narażona na pokusy. Czystość staje się tu jednak szkołą wzmożonego słuchania. Uczy poszukiwania coraz to nowych środków wyrazu. Zmusza człowieka do wysiłku intelektualnego i duchowego. Kiedy nie ma możliwości „zagłaskania” konfliktu, kiedy nie można, jak w małżeństwie, wyjaśnić go przytuleniem - trzeba szukać innej drogi. Trzeba długo się modlić, trzeba rozmawiać, trzeba słuchać po raz dziesiąty tych samych słów, żeby wreszcie pojąć ich sens; żeby wypracować rozwiązanie, na które oboje zgodzą się z czystym sumieniem. W tym rozwiązaniu nie będzie już mężczyzny ani kobiety, ale będą jedno w Chrystusie i Chrystus będzie jeden.

\section{PŁODNI}

Zaraz po swojej konwersji, w uroczystość Wszystkich Świętych I940 roku, Adrienne von Speyr powiedziała do Hansa Ursa von Balthasara: „Bóg zawsze szuka ludzi, którzy w decydującym momencie się nie boją" ${ }^{\circ}$. Adrienne i Hans, rozpoczynając swoje wspólne dzieło i ścisłą współpracę, dużo ryzykowali: również dobrą opinię i zaufanie przełożonych. Nie bali się. Ze wszystkich prób wyszli zwycięsko, pozostając płodnymi - bo tak właśnie mówili o swojej wspólnej pracy. „8 grudnia I946 roku, uroczystość wybrania i doskonałej czystości Maryi Dziewicy, jest [...] decydującą datą w historii współpracy Adrienne i Hansa. Święty Ignacy powiedział im, że dzisiaj zostanie wyraźnie potwierdzone podwójne powołanie (doppelte Sendung) w Kościele. Nowy grunt dla płodności w Kościele. Dotychczas nie jest interpretowane jako bezwartościowe, ale zostanie mu nadana nowa wartość. [...] Święty Ignacy opowiadał kiedyś Hansowi, że przez całe stulecia wielokrotnie podejmowal próby, aby swoim synom jezuitom podarować tak zwane mistyczne oblubienice. Jednak próby te najczęściej kończyły się niepowodzeniem $\mathrm{z}$ powodu braku zrozumienia, odwagi i braku oddania

Io Por. J. S. Neuman, Mężczyzna i kobieta w Bożym Królestwie. Wprowadzenie do życia i dziet Adrienne von Speyr i Hansa Ursa von Balthasara, przeł. J. Iwaszkiewicz, Kielce 2005, s. 57 . 
jednej lub drugiej ze stron. Najczęściej jest tak, mówi Ignacy, że oboje odmawiają przyjęcia daru, ponieważ uważają, że wiedzą lepiej. Oczywiście $\mathrm{w}$ związkach między zakonnikami a kobietami konieczna jest wielka ostrożność, ale kiedy są one udane, to są też bardzo płodne. Dlatego Ignacy chce, aby Balthasar podjął takie zadanie" ".

„Bóg zawsze szuka ludzi, którzy w decydującym momencie się nie boją" Wystarczy tylko w to uwierzyć i podjąć wyzwanie.

\section{Bibliografia}

Kongregacja Nauki Wiary, List do biskupów Kościoła katolickiego o współdziałaniu mężczyzny i kobiety w Kościele i świecie, Rzym 2004.

Jan Paweł II, List apostolski Mulieris dignitatem, Rzym 1998.

Jan Paweł II, Orędzie na xxx Światowy Dzień Środków Społecznego Przekazu, Rzym 1996.

Jan Paweł II, List do kobiet, Rzym 1995.

Jan Paweł II, Mężczyzna i niewiasta stworzyt ich. Chrystus odwotuje sie do „serca”. O Jana Pawta II teologii ciata, Lublin 1987.

Neuman J. S., Mężczyzna i kobieta w Bożym Królestwie. Wprowadzenie do życia $i$ dziet Adrienne von Speyr i Hansa Ursa von Balthasara, przeł. J. Iwaszkiewicz, Kielce 2005.

Rahner K., O możliwości wiary dzisiaj, tlum. A. Morawska, Kraków 1983.

Weigel G., Świadek nadziei, tłum. M. Tarnowska i in., Kraków 2000.

II J. S. Neuman, Mę̇̇czyzna i kobieta w Bożym Królestwie..., dz. cyt., s. III-II2. 